\title{
Spaniophagus, first new Eocene genus of silken fungus beetle from Baltic amber (Coleoptera: Clavicornia: Cryptophagidae)
}

\author{
Spaniophagus, первый род эоџеновых скрытноедов \\ из балтийского янтаря (Coleoptera: Clavicornia: Cryptophagidae)
}

\author{
G.Yu. Lyubarsky1, E.E. Perkovsky ${ }^{2,3}$

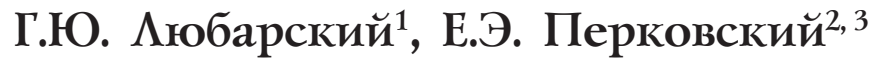

\footnotetext{
${ }^{1}$ Zoological Museum, Moscow Lomonosov State University, Bol'shya Nikitskaya 2, Moscow 125009, Russia. E-mail: lgeorgy@rambler.ru

2 I.I.Schmalhausen Institute of Zoology, National Academy of Sciences of Ukraine, Bogdan Khmielnitsky str. 15, Kiev 01601, Ukraine. E-mail: perkovsk@gmail.com

${ }^{3}$ Borissiak Paleontological Institute, Russian Academy of Sciences, Profsoyuznaya str. 123, Moscow 117997, Russia.

1 Зоологический музей, Московский государственный университет им. М.В. Ломоносова, Большая Никитская ул. 2, Москва 125009, Россия.

${ }^{2}$ Институт зоологии им. И.И. Шмальгаузена, ул. Богдана Хмельницкого 15, Киев 01601, Украина.

${ }^{3}$ Палеонтологический институт им. А.А. Борисяка РАН, Профсоюзная ул. 123, Москва 117997, Россия.
}

KEYWORDS. Baltic amber, Cryptophagidae, Late Eocene, Russia, Spaniophagus.

КЛЮЧЕВЫЕ СЛОВА. Cryptophagidae, Spaniophagus, поздний эоцен, балтийский янтарь, Россия.

ABSTRACT. A new genus, Spaniophagus gen.n. (type species Spaniophagus hoffeinsae sp.n.) is described from the Upper Eocene Baltic amber. The new genus belongs to tribe Cryptophagini. The new genus is similar to the extant genus Spaniophaenus Reitter, 1875, differing from the latter in absent emargination on anterior margin of pronotum and lack of angularity in lateral margin of pronotum. This is the first extinct genus from family Cryptophagidae, described from the Eocene.

РЕЗЮМЕ. Описан новый род Spaniophagus gen.n. (типовой вид Spaniophagus hoffeinsae sp.n.) из верхнеэоценового балтийского янтаря. Новый род относится к трибе Cryptophagini и схож с родом Spaniophaenus Reitter, 1875. Отличается от него отсутствием вырезки на переднем крае переднеспинки и формой бокового края переднеспинки. Это первый вымерший род семейства, описанный из эоцена.

\section{Introduction}

While studying of the fauna of the Eocene Baltic, Rovno and Bitterfeld amber, so far new species have only been found that belong to the genera represented in the modern fauna [Lyubarsky, Perkovsky, 2010, 2011, 2012, 2013, 2018, 2019; Perkovsky, Lyubarsky, 2014]. The Cretaceous fauna Cryptophagidae, on the contrary, is distinguished by a peculiar generic composition [Lyubarsky, Perkovsky, 2014, 2015, 2017a,b, 2018; Peris et al., 2017].
However, a specimen that was found in the Hoffeins collection, should be attributed to a new genus. By all the main characters, this beetle belongs to family Cryptophaginae, tribe Cryptophagini: width of labial palpomere 1 equal to palpomere 2; boss on front of head absent; gular sutures present; tibia slender, not club-shaped; metasubcoxal line absent; tarsi of male 5-5-4; ventrite 5 without tickened setae. For the tribe Cryptophagini the state of the characters is: pronotum with lateral margin modified, with callosity in anterior angle and middle tooth on the sides of pronotum; basal pits of pronotum present. However, for the genus Spaniophaenus Reitter, 1875 (Cryptophagini) the state of characters is: pronotum with lateral margin unmodified; basal pits absent. The new found specimen has the characters as in the genus Spaniophaenus: pronotum with lateral margin unmodified; basal pits absent. This is a typical representative of the tribe Cryptophagini.

In Late Eocene amber was found representatives of subfamily Cryptophaginae (Antherophagus Dejean, 1821, Cryptophagus Herbst, 1792, Micrambe Thomson, 1863, Telmatophilus Heer, 1841) and Atomariinae (Atomaria Stephens, 1829, Ephistemus Stephens, 1829). Recently was described a new Priabonian species: Telmatophilus britannicus Kirejtshuk et Kurochkin, 2019 [Kirejtshuk et al., 2019]. However, genus Spaniophagus differs from Telmatophilus by the tarsal formula of the male (5-5-5 in Telmatophilus).

How to cite this article: Lyubarsky G.Yu., Perkovsky E.E. 2019. Spaniophagus, first new Eocene genus of silken fungus beetle from Baltic amber (Coleoptera: Clavicornia: Cryptophagidae) // Russian Entomol. J. Vol.28. No.3. P.263-268. doi: 10.15298/rusentj.28.3.05 

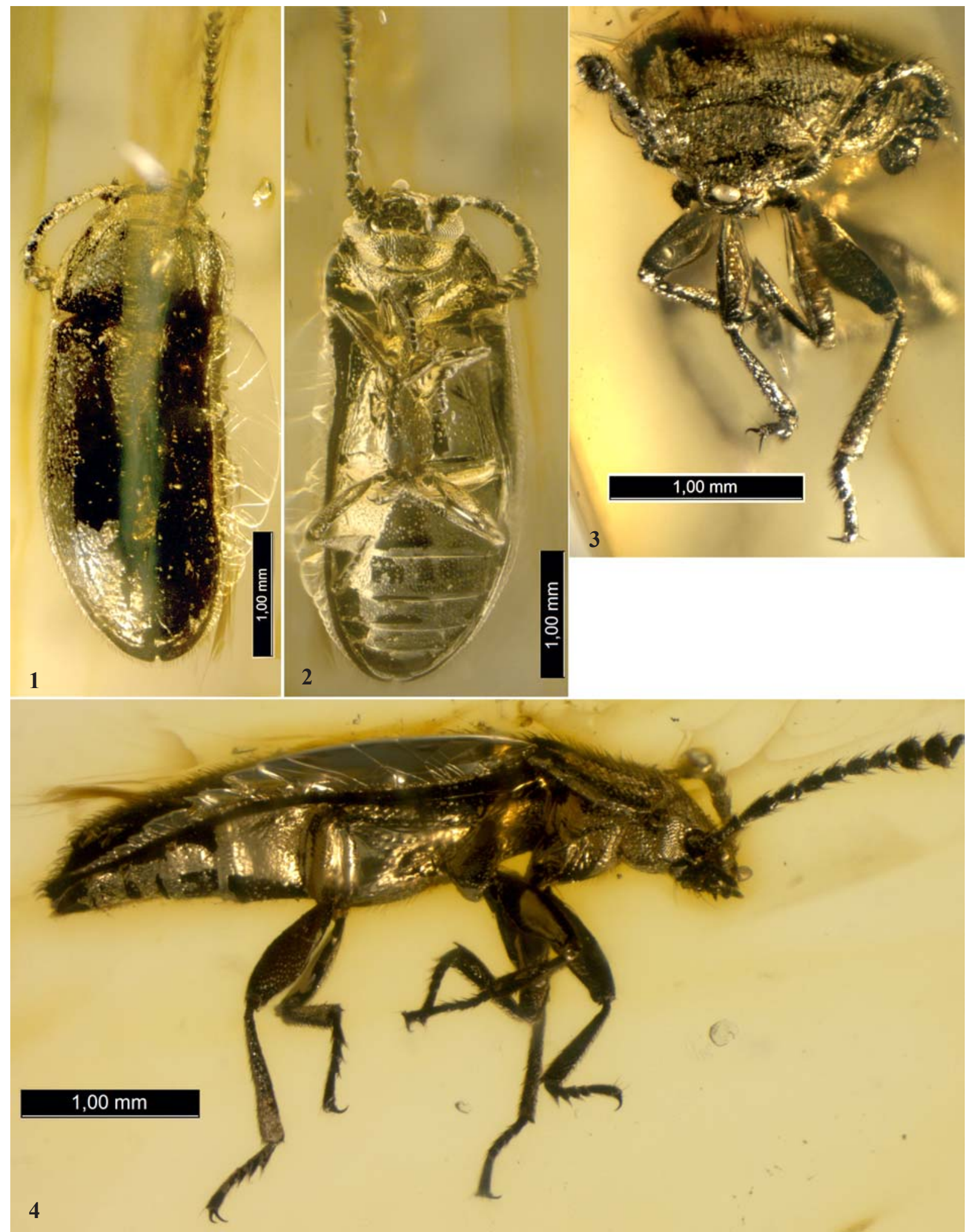

Figs 1-4. Spaniophagus hoffeinsae gen. et sp.n. Holotype (inv. No CCHH 824-4 from the collection of the Senckenberg Deutsches Entomologisches Institut, Müncheberg, Germany (SDEI)): 1 - dorsal; 2 - ventral; 3 - frontal; 4 - lateral.

Рис. 1-4. Spaniophagus hoffeinsae gen. et sp.n. Голотип (inv. No CCHН 824-4 в коллекции Senckenberg Deutsches Entomologisches Institut, Müncheberg, Germany (SDEI)): 1 - сверху; 2 - снизу; 3 - спереди; $4-$ сбоку. 


\section{Taxonomy}

Family CRYPTOPHAGIDAE Kirby, 1826

Subfamily CRYPTOPHAGINAE Kirby, 1826

Genus Spaniophagus Lyubarsky et Perkovsky, gen.n. Figs 1-7. sp.n.

Type species Spaniophagus hoffeinsae Lyubarsky et Perkovsky

DIAGNOSIS. Body shape parallel-sided, moderately convex. Clypeus of male not notched. Antenna clubbed. Pronotum with anterior margin not emarginated; lateral margin not modified, not serrate, sinuate, or explanate; angularity absent; prominent middle tooth absent; sublateral line absent. Tibia slender, not club-shaped. Prosternal process not vaulted. Ventrite 1 longer than remaining ventrites. Tarsal formula 5-5-4 in male.

DESCRIPTION. Color of body dark brown. Body shape parallel-sided, moderately convex (Fig. 1). Punctation of body and elytron confused; punctation dense, distance between puncture on average less than diameter of puncture. Fronto-clypeal suture absent; subgenal spine well-developed; gular sutures present. Antenna clubbed; antennomeres not compact; last antennomere symmetrical and equal in length to penultimate (Fig. 2). Width of labial palpomere 1 equal to palpomere 2. Mentum with transverse ridge. Eye well developed, prominent. Boss on front of head absent (Fig. 3). Pronotum parallel-sided, its width does not decrease from the middle to the base; anterior margin of pronotum not emarginate; sides not explanate; margin unmodified (Fig. 5); angularity absent; prominent middle tooth absent; sublateral line absent; basal pits absent; median fold absent; basal groove absent.

Procoxae wide open posteriorly, separated by prosternal process. Prosternal process not vaulted; longer than anterior portion of prosternum. Mesosternum without parallel lines. Mesocoxae set very closely, width of mesosternal process equal to or $2 / 3$ that of mesocoxa. Epimeron incomplete, extending to metasternum. Metasternal process subdepressed, not beyond mesocoxae. Distance between metacoxae approximately equal to diameter of metacoxa. Metasternum with median longitudinal line (Fig. 7). Metasubcoxal line absent.

Ventrite 1 longer than remaining ventrites, ventrite 5 without thickened setae. Tibia with apical fringle of spines. Tarsi slightly lobed below.

Male. Clypeus not notched. Antennal segments not compact. Ventrite 5 unmodified. Metatibia unmodified. Tarsal formula 554 (Fig 6); tarsomeres 1-3 of pro-, meso- and metatarsi dilated.

ETYMOLOGY. As the new genus is similar to the genera Spaniophaenus and Cryptophagus, the name is a combination of these generic names.

\section{Spaniophagus hoffeinsae \\ Lyubarsky et Perkovsky, sp. n.}

MATERIAL: Holotype, CCHH 824-4, Baltic amber, Yantarnyi, Late Eocene. Sex of the holotype: male. Holotype will be deposited in the amber collection of the Senckenberg Deutsches Entomologisches Institut, Müncheberg, Germany (SDEI).

DESCRIPTION. Length of body $4 \mathrm{~mm}$, maximal width $1.5 \mathrm{~mm}$. Body setae long, adpressed. Head densely punctuate, average width of puncture $0.002 \mathrm{~mm}$, punctures separated by about $3 / 4$ diameter. Interantennal distance $=0.5 \mathrm{~mm}$. Eye prominent, finely faceted, slightly asymmetrical, slightly smaller than the first segment of the antenna. Antenna elongate, extending beyond posterior margin of pronotum. $1^{\text {st }}$ antennal segment slightly longer than $2^{\text {nd }} ; 3^{\text {rd }}$ segment longest, $2 \mathrm{x}$ as long as wide; segments $4-8$ of approximately equal length, $1.5 \mathrm{x}$ as long as wide; $9^{\text {th }}$ and $10^{\text {th }}$ trapezoidal, transversal; $11^{\text {th }}$ oval, slightly asymmetrical.

Pronotum with longitudinal ridges on the sides; possibly the result of necrologic compression, since it is not completely symmetrical. Pronotum about $0.5 \mathrm{x}$ as long as wide. Pronotum is 3.6 times shorter than elytron. Pronotum without angularity, narrowed anteriorly, parallel-sided from middle to base. Lateral margin without teeth. Basal margin with middle lobe, with basal furrow. Punctures of disk separated by about $2 / 3$ diameter, disk of basal portion without microsculpture. Elytra about $1.7 \mathrm{x}$ as long as combined width. Elytral punctures separated by 1.5 diameter. Humeral tooth absent. The maximum width of the elytra is located behind the middle.

Disk of metasternum punctured, punctures separated by 1.5 diameter; small areas near the posterior coxae are smooth, without punctures.

Pro-, meso- and metatibia with two short spurs on apex. Length of pro- and mesotibial spur less than $1 / 3$ width of tibia in apex; length of metatibial spur less than $1 / 6$ width of metatibia in apex. Apex of all tibia with crown of setae. Tarsomeres 1-3 of pro-, meso- and metatarsi weakly dilated; 4th segment almost not expanded. Small lobes on top of long bristles. Claws of tarsi curved, without notches.

Ventrite 1-5 length ratio: 22:11:7:5:6. Ventrites smooth, with weak pubescence on the back margin, weakly punctured, distance between punctures $=2$ diameter.

ETYMOLOGY. The name is given in honor of Christel Hoffeins.

REMARKS. The genus Spaniophagus gen.n. differs from the other genera of the tribe Cryptophagini by several characters common to Spaniophaenus: lateral margin of pronotum not modified; very long ventrite 1 , longer than remaining ventrites; basal pits absent; basal groove absent. On the other hand, the genus Spaniophaenus is among the modern genera in sister relation with the genus Catopochrotus. Perhaps the new genus belongs to the same group of genera.

\section{Discussion}

Some genera of Cryptophagidae live in nests of social Hymenoptera, birds and mammals [Leschen, 1999]. Spaniophagus gen.n. is sister taxon to the genus Spaniophaenus. Spaniophaenus lives in ant and termite nests, under rocks, and in bird nests. Spaniophaenus is sister taxon to the Catopochrotus Reitter, 1889 from modern fauna; Catopochrotus can be also an inquiline in ant nests (Crematogaster Lund, 1831). Crematogaster ants still not found in Baltic amber [Dubovikoff, pers. comm., 2019]; published Baltic record [Perkovsky, 2016] was based on the specimen from copal, deposited in Zoological Institute RAS (StPetersburg). At the same time undisputed Crematogaster is described from Rovno amber [Radchenko, Dlussky, 2019], so it is very possible that described beetle was an inquiline as well. Probably a new genus also lived in the nests of ants.

The modern genera Spaniophaenus and Catopochrotus are saprophagous [Leschen, 1996]. Perhaps 
Spaniophagus gen.n. was also the saprophagous. This is likely explained in part by the lack of a major dietary or habitat shift in myrmecophilous species compared to their free-living ancestors. Similarity in diet has been implicated previously in the evolution of social insect inquilinism in mycophagous Cryptophagidae,

5
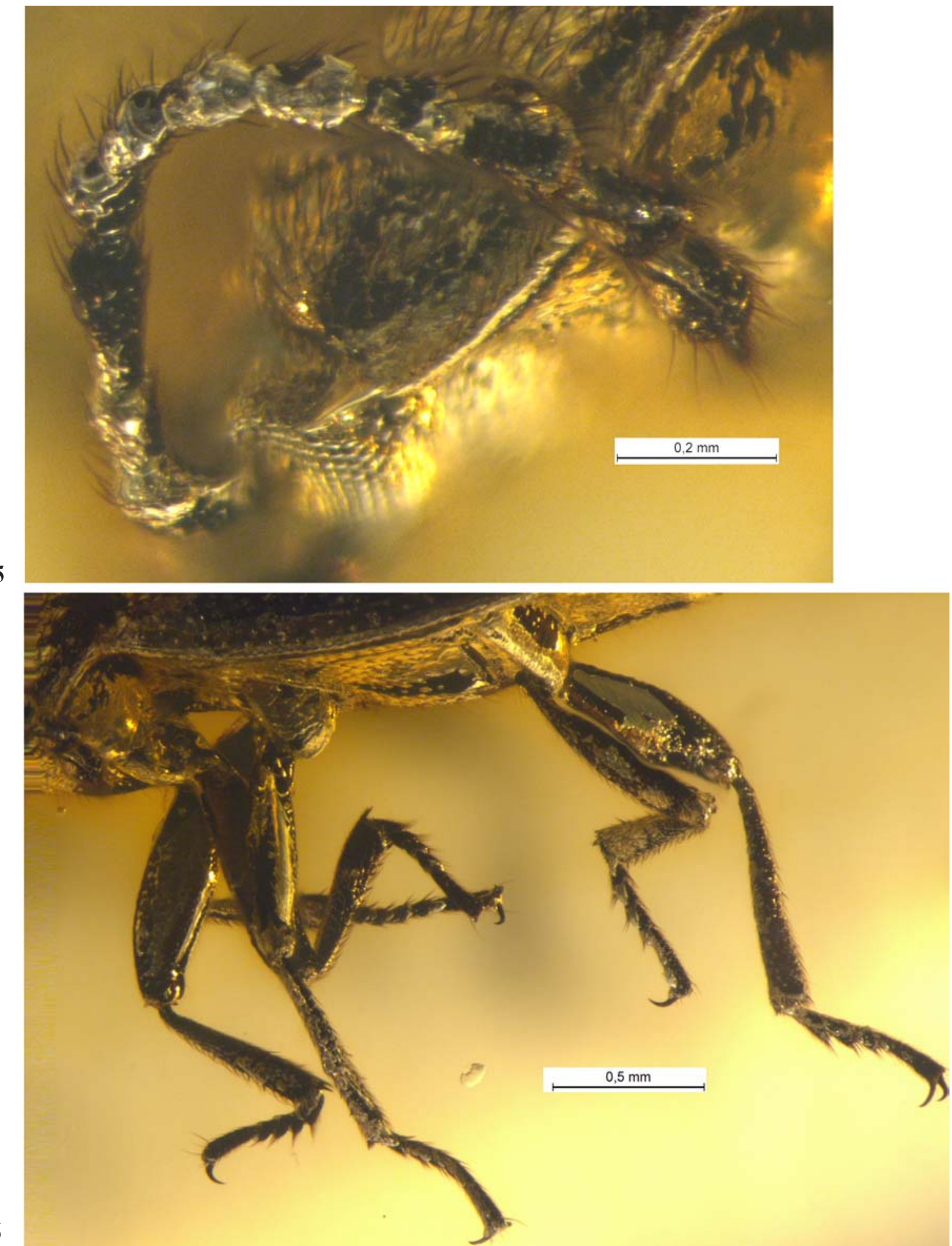

Figs 5-6. Spaniophagus hoffeinsae gen. et sp.n. Holotype (inv. No CCHH 824-4 from the collection of the Senckenberg Deutsches Entomologisches Institut, Müncheberg, Germany (SDEI)): 5 - lateral margin of pronotum; 6 - legs.

Рис. 5-6. Spaniophagus hoffeinsae gen. et sp.n. Голотип (inv. № CCHН 824-4 в коллекции Senckenberg Deutsches Entomologisches Institut, Müncheberg, Germany (SDEI)): 5 - боковой край переднеспинки; 6 - ноги. 


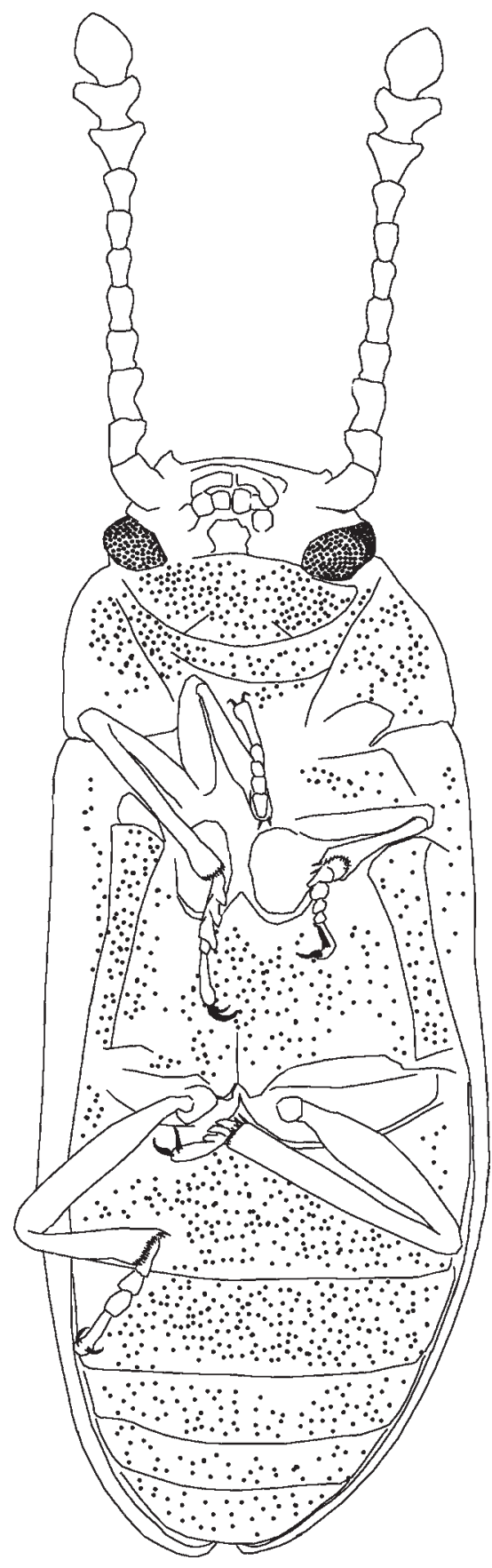

Fig. 7. Drawing of ventral view, Spaniophagus hoffeinsae gen. et sp.n.

Рис. 7. Рисунок вентральной стороны Spaniophagus hoffeinsae gen. et sp.n.

where the decaying nest debris and refuse piles used by myrmecophilous species are little different from the habitats used by free-living relatives [Leschen, 1999; Parker, 2016].

The closest genera for Spaniophagus gen.n. are Spaniophaenus and Catopochrotus. Spaniophaenus is spread in the Western Palaearctic (Europe: Spain, France, Romania, Crimea and Caucasus) [Otero, Diaz Pazos, 1995], and also found in the Himalayas [India, Himachal Pradesh:
Lyubarsky, 1997]. Catopochrotus is spread in Caucasus, Elton and Köpetdag (Bol'shaya Samaroda river, Volgograd area; Maykop, Adygea; Gori, Georgia; Ganja, Azerbaijan; Magtymguly, Turkmenistan). The only species of this genus is named for the ant, in the nests of which this beetle occurs: Catopochrotus crematogastri Reitter, 1889. In the light of these facts, finding Spaniophagus gen.n. in Baltic amber is not unexpected. Spaniophaenus can be wingless and winged, Catopochrotus has fully developed wings. It can be assumed that the extinct Spaniophagus gen.n. also had fully developed wings and was capable of flying.

Within Palearctic region, ants of the genus Crematogaster inhabit almost exclusively arid and semiarid areas, including both the open landscapes and dry forests [Radchenko, 2016]. Probably a new genus also lived in the nests of ants, possibly it was myrmecophilic - at least 137 ant species are known from Baltic amber [Perkovsky, 2016; Radchenko, Perkovsky, 2019]. If Spaniophagus gen.n. was related to ants ecologically similar to Crematogaster, than its rarity at the Baltic amber becomes understandable: such environments are more commom for the Rovno amber forest [Lyubarsky, Perkovsky, 2012 and references herein].

This is the first extinct genus from family Cryptophagidae, described from the Eocene. All other Eocene records belong to extant genera.

Acknowledgments. We are grateful to Christel and Hans Werner Hoffeins (Hamburg, Germany) for providing the material for this study. We would like to thank Vitaly Yu. Nazarenko (Schmalhausen Institute of Zoology, Kiev, Ukraine) and Dmitry A. Dubovikov (St. Petersburg State University) for kindly taking photographs of the specimen. This study was supported by Research project of Zoological Museum of MSU (AAAA-A16-116021660077-3).

\section{References}

Kirejtshuk A.G., Ponomarenko A.G., Kurochkin A.S., Alexeev A.V., Gratshev V.G., Solodovnikov A.Yu., Krell F.-Th., Soriano C. 2019. The beetle (Coleoptera) fauna of the Insect Limestone (late Eocene), Isle of Wight, southern England // Earth and Environmental Science Transactions of the Royal Society of Edinburgh. P.1-88.

Leschen R.A.B. 1996. Phylogeny and revision of the genera of Cryptophagidae (Coleoptera: Cucujoidea) // The University of Kansas science bulletin. Vol.55. P.549-634.

Leschen R.A.B. 1999. Origins of symbiosis: phylogenetic pattens of social insect inquilinism in Cryptophagidae (Coleoptera: Cucujoidea) //G.W. Byers, R.H. Hagen, R.W. Brooks (eds.). Entomological contributions in memory of Byron A. Alexander. Lawrence, Kansas: Natural History Museum. The University of Kansas. P.85-101.

Lyubarsky G.Yu. 1997. Cryptophagidae and Languriidae from India (Coleoptera, Clavicornia) // Entomofauna. Zeitsch. Entomol. Bd.18. No.5. S.49-60.

Lyubarsky G.Yu., Perkovsky E.E. 2010. First Eocene species of the genus Micrambe (Cryptophagidae: Coleoptera, Clavicornia) // Vestnik zoologii. Vol.44. No.3. P.275-279.

Lyubarsky G.Yu., Perkovsky E.E. 2011. Third contribution on Rovno amber silken fungus beetles: a new Eocene species of Cryptophagus (Coleoptera, Clavicornia, Cryptophagidae) // ZooKeys. Vol.130. P.255-261. 
Lyubarsky G.Yu., Perkovsky E.E. 2012. The first Eocene species of the genus Cryptophagus (Coleoptera, Clavicornia, Cryptophagidae) // Vestnik zoologii. Vol.46. No.1. P.83-87.

Lyubarsky G.Yu., Perkovsky E.E. 2013. Fourth contribution on late Eocene amber silken fungus beetles: a new Baltic amber species of Atomaria (Coleoptera, Clavicornia, Cryptophagidae) // Vestnik zoologii. Vol.47. No.3. P.273-276.

Lyubarsky G.Yu., Perkovsky E.E. 2014. New species of the genus Nganasania from Upper Cretaceous of Taymyr (Coleoptera, Cryptophagidae) // Russian Entomological Journal. Vol.23. No.3. P.191-194.

Lyubarsky G.Y., Perkovsky E.E. 2015. New genus Microticus from Upper Cretaceous of Taymyr (Coleoptera: Cryptophagidae), oldest silken fungus beetle with sexually dimorphic tarsal formula // Russian Entomological Journal. Vol.24. No.1. P.61-66.

Lyubarsky G.Yu., Perkovsky E.E. 2017a. New genus Ennoticus from Upper Cretaceous of Taymyr (Coleoptera: Cryptophagidae) // Paleontologicheskii Zhurnal. No.2. P.81-85. [in Russian, English translation: Paleontological Journal. Vol.51. No.2. P.191-195].

Lyubarsky G.Yu., Perkovsky E.E. 2017b. Re-description of the genus Nganasania Zherikhin, 1977 from Upper Cretaceous of Taimyr (Coleoptera: Cryptophagidae) // Russian Entomological Journal. Vol.26. No.3. P.251-255.

Lyubarsky G.Yu., Perkovsky E.E. 2018. First species of Atomaria (Coleoptera: Clavicornia: Cryptophagidae) from Bitterfeld amber and several notes on Miocene and Cretaceous Cryptophagidae // Russian Entomological Journal. Vol.27. No.4. P.381-385.

Lyubarsky G.Yu., Perkovsky E.E. 2019. First species of Ephistemus (Coleoptera: Clavicornia: Cryptophagidae) from Baltic amber //
Russian Entomol. J. Vol.28. No.1. P.54-57. doi: 10.15298/ rusentj.28.1.07

Otero J.C., Diaz Pazos J.A. 1995. Revision of the genus Spaniophaenus Reitter, 1875 (Coleoptera: Cryptophagidae) // Koleopterologische Rundschau. Bd.65. S.183-188.

Parker J. 2016. Myrmecophily in beetles (Coleoptera): evolutionary patterns and biological mechanisms // Myrmecological News. Vol.22. P.65-108.

Peris D., Lyubarsky G.Yu., Perkovsky E.E. 2017. A new genus of silken-fungus beetle (Coleoptera: Cryptophagidae) from the Spanish Cretaceous amber // Cretaceous Research. Vol.78. P.191-195.

Perkovsky E.E. 2016. Tropical and Holarctic ants in Late Eocene ambers // Vestnik zoologii. Vol.50. No.2. P.111-122.

Perkovsky E.E., Lyubarsky G.Yu. 2014. Fifth contribution on silken fungus beetles from Late Eocene amber: a second Baltic amber species of Atomaria (Coleoptera: Clavicornia: Cryptophagidae) // Russian Entomological Journal. Vol.23. No.1. P. 41-44.

Radchenko A.G. 2016. [Ants (Hymenoptera, Formicidae) of Ukraine]. Kiev: Institute of Zoology of the National Academy of Sciences of Ukraine. 495 p. [In Russian]

Radchenko A.G., Dlussky G.M. 2019. First record of the ant genus Crematogaster (Hymenoptera: Formicidae) from the Late Eocene European ambers // Annales Zoologici. Vol.69. No.2. P.417421.

Radchenko A.G., Perkovsky E.E. 2020 (in press). New records of the fossil ant genus Prionomyrmex Mayr (Hymenoptera, Formicidae, Myrmeciinae) from Late Eocene European Ambers // Palaeontological journal. Vol.54. 